\title{
Talarodiolide, a New 12-Membered Macrodiolide, and GC/MS Investigation of Culture Filtrate and Mycelial Extracts of Talaromyces pinophilus
}

\author{
Maria Michela Salvatore ${ }^{1}$ (1), Marina DellaGreca ${ }^{1}$, Rosario Nicoletti ${ }^{2,3}{ }^{(0)}$, Francesco Salvatore ${ }^{1}$, \\ Francesco Vinale $^{4}$ (D), Daniele Naviglio ${ }^{1}$ (D) and Anna Andolfi ${ }^{1, *}$ \\ 1 Department of Chemical Sciences, University of Naples 'Federico II', 80126 Naples, Italy; \\ mariamichela.salvatore@unina.it (M.M.S.); dellagre@unina.it (M.D.); frsalvat@unina.it (F.S.); \\ naviglio@unina.it (D.N.) \\ 2 Council for Agricultural Research and Agricultural Economy Analysis, 00184 Rome, Italy; \\ rosario.nicoletti@crea.gov.it \\ 3 Department of Agriculture, University of Naples 'Federico II', 80055 Portici, Italy \\ 4 Institute for Sustainable Plant Protection, National Research Council, 80055 Portici (NA), Italy; \\ francesco.vinale@ipsp.cnr.it \\ * Correspondence: andolfi@unina.it; Tel.: +39-081-2539179
}

Received: 23 March 2018; Accepted: 17 April 2018; Published: 19 April 2018

\begin{abstract}
Talarodiolide, a new 12-membered macrodiolide, was isolated and characterized from the culture filtrate of strain LT6 of Talaromyces pinophilus. The structure of (Z)-4,10-dimethyl-1,7-dioxacyclododeca-3,9-diene-2,8-dione was assigned essentially based on NMR and MS data. Furthermore, several known compounds were isolated and identified in the crude extract of the culture filtrate and mycelium of this strain. EI mass spectrum at $70 \mathrm{eV}$ of all isolated metabolites was acquired and compiled in a custom GC/MS library to be employed to detect metabolites in the crude extracts.
\end{abstract}

Keywords: Talaromyces pinophilus; talarodiolide; macrodiolides; GC/MS; secondary metabolites

\section{Introduction}

With a widespread occurrence in very diverse environmental contexts, from the soil to the sea [1-3], the species Talaromyces pinophilus (=Penicillium pinophilum) (Eurotiales: Trichocomaceae) has received increasing attention in mycological research for its ability to act as a fungal antagonist and plant-growth promoter $[1,4,5]$, and for possible biotechnological applications based on the production of enzymes [6,7] and bioactive metabolites [8-10].

Two strains (LT4 and LT6), possibly deriving from the same wild clone since they were both recovered from the rhizosphere of a tobacco plant cropped near Lecce (Apulia, Southern Italy), have been particularly studied in our laboratories after they were shown to produce a novel fungitoxic and cytostatic compound named 3-O-methylfunicone (OMF) $[1,11]$. OMF is part of a homogeneous family comprising about 20 structurally related secondary metabolites which have been mainly characterized from cultures of Talaromyces strains [12]. It has notable antitumor properties based on several biomolecular mechanisms of action resulting from a series of preclinical assays [13-17]. Although it represents the main extrolite produced by our strains, other funicone variants have been occasionally extracted $[18,19]$, indicating that some factors act during the culturing cycle which may lead to the accumulation of intermediate or side products. Within our recent activity aiming at the standardization of OMF production, additional compounds were detected from cultures of strain LT6. Among them, a new product with an unusual structure for a natural compound, namely talarodiolide, was purified from its culture filtrates. Furthermore, the present paper reports findings from the 
first GC/MS-based investigation on secondary metabolites in culture filtrate and mycelial extracts of T. pinophilus.

\section{Results}

\subsection{Isolation and Identification of Metabolites}

The crude $\mathrm{CHCl}_{3}$ extract from the culture filtrates of T. pinophilus strain LT6 was purified by combined column (CC) and thin layer chromatography (TLC), leading to isolation of one new (1, Figure 1) and four known compounds (2-5, Figure 1). Structures of known compounds were confirmed by comparison of data obtained from OR, ${ }^{1} \mathrm{H}$ and ${ }^{13} \mathrm{C}-\mathrm{NMR}$, and ESI-TOF MS with those reported in the literature for OMF [11], cyclo-(S-Pro-R-Leu), cyclo-(S-Pro-S-Ile) [20], and cyclo-(S-Pro-S-Phe) [21] (2-5).<smiles>CC(C)=CC(=O)OCCOC(=O)C=C(C)C</smiles>

1<smiles>C/C=C/c1occ(C(=O)c2c(OC)cc(OC)cc2C(=O)OC)c(=O)c1OC</smiles><smiles>CC(C)CC1NC(=O)C2CCCN2C1=O</smiles>

3<smiles>C/C=C/c1cc(=O)c(C2OC(=O)c3cc(OC)cc(O)c32)co1</smiles><smiles>COc1cc(OC)c2c(c1)C(=O)OC2c1coc(C)cc1=O</smiles><smiles>COc1c([C@@H](O)CC(C)C)ccc2c1C(=O)OCc1cc(C)cc(O)c1O2</smiles><smiles>CCCCC/C=C/C/C=C/CCCCCCCC(=O)OCC(O)CO</smiles>

Figure 1. Structures of talarodiolide, 3-O-methylfunicone, cyclo-(S-Pro- $R$-Leu), cyclo-(S-Pro-S-Ile), cyclo-(S-Pro-S-Phe), vermistatin, penisimplicissin, penicillide, and 1-glycerol-linoleate (1-9), compounds produced by Talaromyces pinophilus LT6, isolated by preparative chromatographic methods and identified by spectroscopic and MS techniques.

Compound 1, isolated as amorphous solid, has a molecular weight of $224 \mathrm{~m} / \mathrm{z}$ accounting for a molecular formula of $\mathrm{C}_{12} \mathrm{H}_{16} \mathrm{O}_{4}$ and the index of hydrogen deficiency is five as deduced from ESI-TOF MS. The ${ }^{1} \mathrm{H}-\mathrm{NMR}$ spectrum (Table 1 and Figure S1) revealed one broad singlet methyl, one broad triplet and one triplet in aliphatic region, and a broad singlet of olefinic signals. In the ${ }^{13} \mathrm{C}-\mathrm{NMR}$ spectrum (Table 1 and Figure S5), only six carbon signals were present indicating a highly symmetric molecule. The ${ }^{1} \mathrm{H}$ and ${ }^{13} \mathrm{C}$ resonances of 1 were assigned by combination of COSY and HSQC experiments. The COSY experiment showed homocorrelations among the olefinic proton at $\delta 5.84$ with the methyl at $\delta 2.03$ and methylene at $\delta 2.40$, the latter of which was also correlated with methylene at $\delta 4.40$. The HSQC (Figure S3) spectrum showed correlations of methyl at $\delta 2.03$ with carbon at $\delta 22.4$, two methylenes at $\delta 2.40$ and 4.40 with carbons at $\delta 29.2$ and 65.8 , respectively, and one methine at $\delta 5.84$ 
with carbon 116.8. The carbons at $\delta 164.6$ and 157.7 were assigned to a carboxyl group and substituted $\mathrm{sp}^{2}$ carbon, respectively. According to the structure in the HMBC (Figure S4) spectrum, the $\mathrm{H}_{2}-6 / \mathrm{H}_{2}-12$ protons were correlated to the C-8/C-2 at 164.4, C-4/C-10 at 157.7 and C-5/C-11 at 29.2. Furthermore, the $\mathrm{H}_{3}-13 / \mathrm{H}_{3}-14$ protons were correlated to C-3/C-9, C-4/C-10 and C-5/C-11 carbons. The analysis of NOESY (Figure S6) spectrum evidenced NOE of the methyl at $\delta 2.03$ and olefinic H-3 proton indicating a $\mathrm{Z}$ configuration at double bond.

Table 1. NMR data and HMBC correlations for talarodiolide (1) recorded in $\mathrm{CDCl}_{3}$.

\begin{tabular}{cccc}
\hline Position & $\delta_{\mathrm{C}}$ & $\delta_{\mathrm{H}}(\mathrm{J}$ in Hz$)$ & HMBC \\
\hline 2,8 & $164.6 \mathrm{C}$ & - & \\
3,9 & $116.8 \mathrm{CH}$ & $5.84, \mathrm{brs}$ & \\
4,10 & $157.7 \mathrm{C}$ & - & \\
5,11 & $29.2 \mathrm{CH}_{2}$ & $2.40, \mathrm{brt}, 6.3$ & \\
6,12 & $65.8 \mathrm{CH}_{2}$ & $4.40, \mathrm{t}, 6.3$ & $\mathrm{C}-8 / \mathrm{C}-2, \mathrm{C}-4 / \mathrm{C}-10, \mathrm{C}-5 / \mathrm{C}-11$ \\
13,14 & $22.4 \mathrm{CH}_{3}$ & $2.03, \mathrm{brs}$ & $\mathrm{C}-3 / \mathrm{C}-9, \mathrm{C}-4 / \mathrm{C}-10, \mathrm{C}-5 / \mathrm{C}-11$ \\
\hline
\end{tabular}

These results and the molecular formula of $\mathrm{C}_{12} \mathrm{H}_{16} \mathrm{O}_{4}$ suggest that $\mathbf{1}$ is a symmetrical macrodiolides, (Z)-4,10-dimethyl-1,7-dioxa-cyclododeca-3,9-diene-2,8-dione. This structure was confirmed by data from ESI-TOF MS recorded in positive mode. The spectrum showed the sodiated dimeric, dimeric, sodiated and pseudomolecular ions $[2 \mathrm{M}+\mathrm{Na}]^{+},[2 \mathrm{M}+\mathrm{H}]^{+},[\mathrm{M}+\mathrm{Na}]^{+}$, and $[\mathrm{M}+\mathrm{H}]^{+}$ at $m / z 471,449,247$, and 225 , respectively.

Symmetric macrodiolides have been reported from many natural sources, and displayed some interesting effects, such as antibacterial, antifungal and cytotoxic activities ([22] and literature therein). However, in the light of the current knowledge, no 12-membered macrodiolide has been isolated from natural sources so far.

In addition, the production of secondary metabolites by T. pinophilus LT6 was investigated after extraction of mycelium. Extraction and purification procedures (CC and TLC) afforded the isolation of OMF (2), and other known compounds identified as vermistatin (6) [23], penisimplicissin (7) [24], penicillide (8) [25], and 1-glycerol-linoleate (9) (Figure 1). In the case of 9, preliminary NMR investigation showed typical signals of monoglycerides of polyunsaturated fatty acids [26]. GC/MS measurements confirmed NMR data and unequivocally revealed the presence of this monoglyceride by comparing its mass spectrum with the reference mass spectra gathered in NIST 14 Mass Spectral library (2014) [27].

\subsection{GC/MS Analysis}

In this study, an EI mass spectrum at $70 \mathrm{eV}$ of all isolated metabolites was acquired and compiled in a custom MS target library to be employed to detect metabolites separated in the crude extracts. GC/MS measurements served several purposes within our strategy. First, when the mass spectrum of the metabolite could be retrieved from a MS database, the acquired mass spectrum provided a definitive proof of its identity, as in the case of cyclo-(S-Pro-R-Leu).

When no mass spectrum satisfactorily matches the acquired mass spectrum could be inferred from a database, the unknown metabolite had to be otherwise identified (e.g., via ESI-TOF MS and ${ }^{1} \mathrm{H} /{ }^{13} \mathrm{C}-\mathrm{NMR}$ mono- and bi-dimensional), but interpretation of the acquired mass spectrum served as a guide in the identification process by setting restrictions on possible structures.

In all cases, the acquired mass spectrum was incorporated into the custom MS library to be used for interpreting GC/MS measurements to be performed directly on samples of mycelium and culture filtrates extracts obtained. Table 2 shows data collected via GC/MS of the identified metabolites. 
Table 2. GC/MS analysis of the crude extract of culture filtrate (A) and mycelium (B) of T. pinophilus LT6.

\begin{tabular}{|c|c|c|c|c|c|}
\hline Metabolite & Code & Diagnostic Ions $m / z$ (Abundance) & RI & $\begin{array}{l}\text { A\% of Total } \\
\text { Ion Current }\end{array}$ & $\begin{array}{l}\text { B\% of Total } \\
\text { Ion Current }\end{array}$ \\
\hline Talarodiolide & 1 & $\begin{array}{c}224[\mathrm{M}]^{\bullet+}(5), 209\left[\mathrm{M}-\mathrm{Me}^{+}(4), 194[\mathrm{M}-\right. \\
2 \mathrm{Me}^{+}(35), 149\left[\mathrm{M}-2 \mathrm{Me}-\mathrm{CO}_{2}-\mathrm{O}^{+}\right. \\
(60), 70\left[\mathrm{M}-\mathrm{C}_{8} \mathrm{H}_{9} \mathrm{O}_{3}\right]^{+}(100)\end{array}$ & 2064 & 3.55 & \\
\hline 3-O-Methylfunicone & 2 & $\begin{array}{c}388[\mathrm{M}]^{\bullet+}(40), 373\left[\mathrm{M}-\mathrm{Me}^{+}(15), 357[\mathrm{M}\right. \\
-2 \mathrm{Me}^{+}, 223\left[\mathrm{M}-\mathrm{C}_{9} \mathrm{O}_{3} \mathrm{H}_{9}\right]^{+}(65), 192[\mathrm{M} \\
\left.\quad-2 \mathrm{Me}-\mathrm{C}_{9} \mathrm{O}_{3} \mathrm{H}_{9}\right]^{+}(100)\end{array}$ & 3006 & 15.26 & 38.12 \\
\hline Cyclo-(Pro-Leu) & 3 & $\begin{array}{c}195\left[\mathrm{M}-\mathrm{Me}^{+}(5), 154\left[\mathrm{M}-\mathrm{C}_{4} \mathrm{H}_{9}\right]^{+}(100)\right. \\
125\left[\mathrm{M}-\mathrm{C}_{6} \mathrm{H}_{13}\right]^{+}(15), 111\left[\mathrm{M}-\mathrm{C}_{7} \mathrm{H}_{15}\right]^{+} \\
(3), 70\left[\mathrm{M}-\mathrm{C}_{7} \mathrm{NO}_{2} \mathrm{H}_{11}\right]^{+}(75)\end{array}$ & 2068 & 11.06 & \\
\hline Cyclo-(Pro-Ile) & 4 & $\begin{array}{c}154\left[\mathrm{M}-\mathrm{C}_{4} \mathrm{H}_{9}\right]^{+}(100), 125\left[\mathrm{M}-\mathrm{C}_{6} \mathrm{H}_{13}\right]^{+} \\
(120), 111\left[\mathrm{M}-\mathrm{C}_{7} \mathrm{H}_{15}\right]^{+}(5), 70[\mathrm{M}- \\
\left.\mathrm{C}_{7} \mathrm{NO}_{2} \mathrm{H}_{11}\right]^{+}(65)\end{array}$ & 2039 & 6.90 & \\
\hline Cyclo-(Pro-Phe) & 5 & $\begin{array}{c}244[\mathrm{M}]^{\bullet+}(34), 215\left[\mathrm{M}-\mathrm{C}_{2} \mathrm{H}_{4}\right]^{+}(3), 153 \\
{\left[\mathrm{M}-\mathrm{C}_{6} \mathrm{H}_{5}-\mathrm{CH}_{2}\right](28), 125\left[\mathrm{M}-\mathrm{C}_{3} \mathrm{H}_{6}-\right.} \\
\left.\mathrm{C}_{6} \mathrm{H}_{5}\right](100)\end{array}$ & 2443 & 2.93 & \\
\hline Vermistatin & 6 & $\begin{array}{c}328[\mathrm{M}]^{\bullet+}(100), 313\left[\mathrm{M}-\mathrm{Me}^{+}(10), 285\right. \\
{\left[\mathrm{M}-\mathrm{Me}-\mathrm{C}_{2} \mathrm{H}_{4}\right]^{+}(48), 165\left[\mathrm{M}-\mathrm{C}_{2} \mathrm{H}_{4}-\right.} \\
\left.\mathrm{C}_{8} \mathrm{O}_{2} \mathrm{H}_{8}\right]^{+}(43)\end{array}$ & 3105 & 0.424 & 1.124 \\
\hline Penisimplicissin & 7 & $\begin{array}{c}302[\mathrm{M}]^{\bullet+}(100), 287\left[\mathrm{M}-\mathrm{Me}^{+}, 273[\mathrm{M}-\right. \\
2 \mathrm{Me}^{+}(17), 175\left[\mathrm{M}-\mathrm{Me}-\mathrm{C}_{6} \mathrm{H}_{7} \mathrm{O}_{2}\right](14) \\
165\left[\mathrm{M}-\mathrm{C}_{8} \mathrm{O}_{2} \mathrm{H}_{8}\right]^{+}(47)\end{array}$ & 2835 & 1.328 & 0.39 \\
\hline Penicillide & 8 & $\begin{array}{c}372[\mathrm{M}-\mathrm{Me}]^{+}(16), 269[\mathrm{M}-2 \mathrm{Me}- \\
\left.\mathrm{C}_{5} \mathrm{OH}_{10}\right](100), 253\left[\mathrm{M}-\mathrm{Me}-\mathrm{OCH}_{3}-\right. \\
\left.\mathrm{C}_{5} \mathrm{OH}_{10}\right](20)\end{array}$ & 3103 & 3.64 & 6.71 \\
\hline 1-glycerol-linoleate & 9 & $\begin{array}{l}354[\mathrm{M}]^{\bullet+}{ }^{+}(4), 336\left[\mathrm{M}-\mathrm{OH}^{+}, 262[\mathrm{M}-\right. \\
\left.\mathrm{C}_{3} \mathrm{O}_{3} \mathrm{H}_{7}\right]^{+}(63), 234\left[\mathrm{M}-\mathrm{C}_{4} \mathrm{O}_{4} \mathrm{H}_{7}\right]^{+}(12)\end{array}$ & 2076 & & 4.19 \\
\hline $\begin{array}{l}\text { Methyl ester of } \\
\text { palmitic acid }\end{array}$ & 10 & [27] & 2020 & & 5.73 \\
\hline $\begin{array}{l}\text { Methyl ester of } \\
\text { linoleic acid }\end{array}$ & 11 & [27] & 2146 & & 17.211 \\
\hline $\begin{array}{l}\text { Methyl ester of } \\
\text { stearic acid }\end{array}$ & 12 & [27] & 2158 & & 1.76 \\
\hline Linoleic acid & 13 & [27] & 2169 & & 6.64 \\
\hline
\end{tabular}

Figure $2 \mathrm{a}, \mathrm{b}$ shows the total ion chromatograms (TICs) of the extracts of culture filtrate and mycelium, respectively.

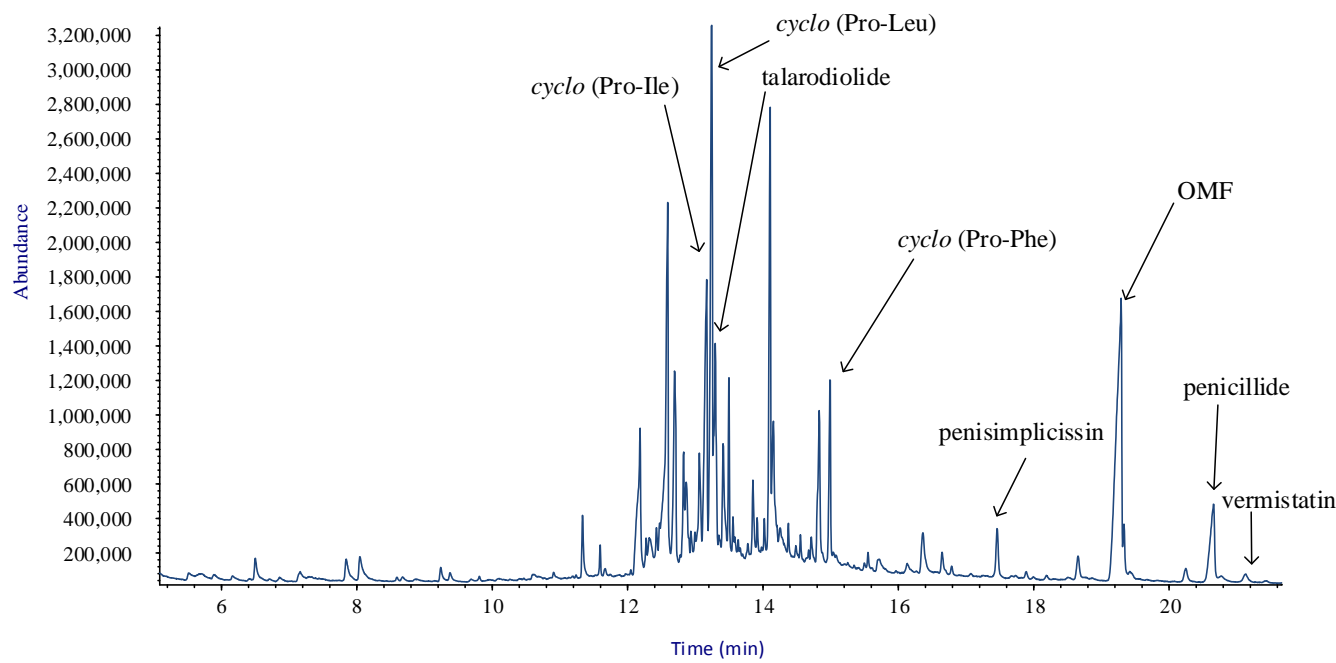

(a)

Figure 2. Cont. 


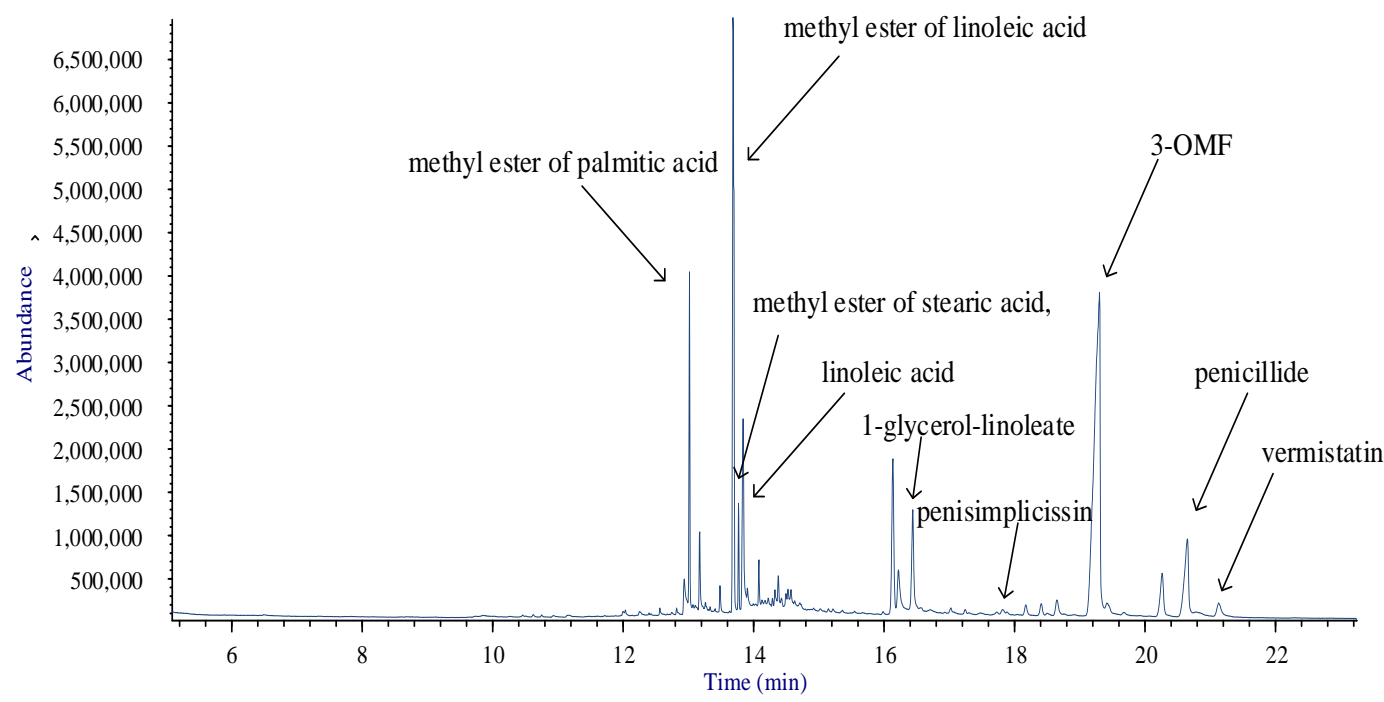

(b)

Figure 2. Annotated total ion chromatograms (TICs) acquired by: culture filtrate extract (a); and mycelial extract $(\mathbf{b})$ of T. pinophylus.

Apart from the isolated metabolites, Figure $2 b$ shows the presence of some fatty acids and their methyl esters in the mycelial extract. In fact, due to the high sensitivity of this technique, GC/MS was able to detect them, combining the retention indices and the reference mass spectra gathered in NIST 14 Mass Spectral library (2014) [27].

Within the framework of the overall strategy, a very important outcome of the procedures arises from the fact that crude extracts were analyzed by GC/MS to check the presence of the isolated metabolites. Notwithstanding some metabolites were not isolated from the culture filtrate, AMDIS attributes peaks in the TIC, as in the case of penicillide, vermistatin and penisimplicissin. Hence, GC/MS analysis is very useful in assessing the possible diversity in the pattern of metabolites extracted from the different sources. With exception of talarodiolide, 1-glycerol-linoleate and the diketopiperazines, all metabolites were detected in both crude extracts, while fatty acids and their esters (10-13) are present in the mycelial extract only. This is in line with the reported occurrence of the latter compounds in the cell membrane of fungi [28].

\section{Materials and Methods}

\subsection{General Experimental Procedures}

Optical rotations were measured in $\mathrm{CHCl}_{3}, \mathrm{CH}_{3} \mathrm{OH}$, and $\mathrm{C}_{2} \mathrm{H}_{5} \mathrm{OH}$ on a Jasco P-1010 digital polarimeter; ${ }^{1} \mathrm{H}$ and ${ }^{13} \mathrm{C}-\mathrm{NMR}$ spectra were recorded at $400 / 100 \mathrm{MHz}$ in $\mathrm{CDCl}_{3}$ or in $\mathrm{CD}_{3} \mathrm{OD}$ on Bruker (Bremen, Germany) spectrometers. The same solvent was used as internal standard. 2D NMR experiments were performed using Bruker microprograms. ESI-TOF mass spectra have been measured on an Agilent Technologies QTOF 6230 in the positive ion mode (Milan, Italy).

Analytical and preparative TLC were performed on silica gel plates (Kieselgel 60, F254, 0.25 and $0.5 \mathrm{~mm}$, respectively) (Merck, Darmstadt, Germany). The spots were visualized by exposure to UV radiation (253), or by spraying first with $10 \% \mathrm{H}_{2} \mathrm{SO}_{4}$ in $\mathrm{MeOH}$ followed by heating at $110{ }^{\circ} \mathrm{C}$ for $10 \mathrm{~min}$. Column chromatography was performed on silica gel column (Merck, Kieselgel 60, 0.063-0.200 mm).

GC/MS measurements were performed with an Agilent 6850 GC equipped with an HP-5MS capillary column (5\% phenyl methyl polysiloxane stationary phase) and the Agilent 5973 Inert MS detector (used in the scan mode). Helium was employed as the carrier gas, at a flow rate of $1 \mathrm{~mL} / \mathrm{min}$. The injector temperature was $250{ }^{\circ} \mathrm{C}$ and during the run a temperature ramp raised the column temperature from $70{ }^{\circ} \mathrm{C}$ to $280{ }^{\circ} \mathrm{C}: 70{ }^{\circ} \mathrm{C}$ for $1 \mathrm{~min} ; 10^{\circ} \mathrm{C} \mathrm{min}-1$ until reaching $170{ }^{\circ} \mathrm{C}$; and $30^{\circ} \mathrm{C} \mathrm{min}^{-1}$ 
until reaching $280{ }^{\circ} \mathrm{C}$. Then it was held at $280{ }^{\circ} \mathrm{C}$ for $5 \mathrm{~min}$. The electron impact (EI) ion source was operated at $70 \mathrm{eV}$ and at $200^{\circ} \mathrm{C}$. The quadrupole mass filter was kept at $250^{\circ} \mathrm{C}$ and was programmed to scan the range $45-550 \mathrm{~m} / \mathrm{z}$ at a frequency of $3.9 \mathrm{~Hz}$.

\subsection{Culture Filtrate Preparation}

Liquid cultures were prepared by inoculating mycelial plugs from actively growing cultures of strain LT6 in 1 L-Erlenmayer flasks containing $500 \mathrm{~mL}$ potato-dextrose broth (PDB, Himedia) which were kept in darkness on stationary phase at $25^{\circ} \mathrm{C}$. After 21 days, cultures were filtered at $0.45 \mu \mathrm{m}$, and the culture filtrates were concentrated in a lyophilizer until reduction to $1 / 10$ of the starting volume. The mycelial cake floating on the broth was collected separately and stored at $-20{ }^{\circ} \mathrm{C}$.

\subsection{Extraction and Isolation of Metabolites from Liquid Cultures}

The freeze-dried culture filtrates $(6 \mathrm{~L})$ were dissolved in $600 \mathrm{~mL}$ of pure water $(\mathrm{pH} 4)$ and extracted with same volume of $\mathrm{CHCl}_{3}$ for three times. The organic extracts were combined, dried on $\mathrm{Na}_{2} \mathrm{SO}_{4}$, and evaporated under reduced pressure to give a yellowish oil residue $(75.3 \mathrm{mg})$.

The residue was submitted to fractionation on silica gel column $(1.5 \times 30 \mathrm{~cm} \mathrm{i.} \mathrm{d})$, eluted with $\mathrm{CHCl}_{3} /$ iso-PrOH $(98: 2, v / v)$. Seven homogeneous fraction groups were collected (A $0.7 \mathrm{mg}$, B $2.7 \mathrm{mg}$, C $9.5 \mathrm{mg}$, D $0.8 \mathrm{mg}$, E $3.4 \mathrm{mg}$, F $9.3 \mathrm{mg}$, G $8.2 \mathrm{mg}$ ). The residue of fraction C was purified by TLC on silica gel eluted with $n$-hexane-acetone $(6: 4, v / v)$ yielding an amorphous solid, talarodiolide $\left(1,1.5 \mathrm{mg}, \mathrm{R}_{\mathrm{f}} 0.41\right.$ on TLC on silica gel eluent $n$-hexane-acetone $\left.(6: 4, v / v)\right)$, and a crystalline solid, $\operatorname{OMF}\left(2,3.5 \mathrm{mg}, \mathrm{R}_{\mathrm{f}} 0.47\right.$ on TLC on silica gel eluent $n$-hexane-acetone $\left.(6: 4, v / v)\right)$. The residue of the fraction $\mathrm{F}$ was further purified by TLC on silica gel eluted with $\mathrm{CHCl}_{3} /$ iso-PrOH $(95: 5, v / v)$ giving as amorphous solids: cyclo-(S-Pro-R-Leu) $\left(3,1.0 \mathrm{mg}, \mathrm{R}_{\mathrm{f}} 0.49\right.$ on TLC on silica gel eluent $\mathrm{CHCl}_{3}-i$-PrOH $(95: 5, v / v))$, cyclo-(S-Pro-S-Ile) $\left(4,2.3 \mathrm{mg}, \mathrm{R}_{\mathrm{f}} 0.35\right.$ on TLC on silica gel eluent $\left.\mathrm{CHCl}_{3}-i-\mathrm{PrOH}(95: 5, v / v)\right)$, and cyclo-(S-Pro-S-Phe) $\left(5,1.5 \mathrm{mg}, \mathrm{R}_{\mathrm{f}} 0.32\right.$ on TLC on silica gel eluent $\left.\mathrm{CHCl}_{3}-i-\mathrm{PrOH}(95: 5, v / v)\right)$.

\subsection{Extraction and Isolation of Metabolites from Mycelium}

Fresh mycelium was homogenized in a mixer with $440 \mathrm{~mL}$ of $\mathrm{MeOH}-\mathrm{H}_{2} \mathrm{O}(\mathrm{NaCl} 1 \%)$ mixture $(55: 45, v / v)$. The suspension was stirred in the dark at room temperature for $4 \mathrm{~h}$. After this period, the suspension was centrifuged $\left(40 \mathrm{~min}\right.$ at $7000 \mathrm{rpm}, 10{ }^{\circ} \mathrm{C}$ ) and separated from the supernatant. The residue was overnight extracted with $250 \mathrm{~mL}$ of the mixture reported above. The suspension was centrifuged, and both supernatants were combined for the subsequent extraction with $\mathrm{CHCl}_{3}$. The organic extracts were combined, dried on anhydrous $\mathrm{Na}_{2} \mathrm{SO}_{4}$, and evaporated under reduced pressure yielding crude extract as a red oil $(230.2 \mathrm{mg})$. The extract was fractionated by CC on silica gel $(1.5 \times 40 \mathrm{~cm}$ i. d. $)$, eluting with $\mathrm{CHCl}_{3} /$ iso- $\mathrm{PrOH}(97: 3, v / v)$. The last fraction was eluted with $\mathrm{MeOH}$. Seven homogeneous fraction groups were collected (A $16.0 \mathrm{mg}, \mathrm{B} 16.4 \mathrm{mg}, \mathrm{C} 12.2 \mathrm{mg}$, D $14.2 \mathrm{mg}$, E $9.8 \mathrm{mg}$, F $29.1 \mathrm{mg}, \mathrm{G} 66.2 \mathrm{mg}$ ). The residue of fraction B was identified as OMF (2). Fraction C was purified by TLC on silica gel eluted with $n$-hexane/acetone $(6: 4, v / v)$ to afford a further amount of OMF (5.6 mg), a crystalline compound identified as vermistatin $\left(6,1.5 \mathrm{mg}, \mathrm{R}_{\mathrm{f}} 0.37\right.$ on TLC on silica gel eluent $n$-hexane-acetone $(6: 4, v / v))$, and an amorphous solid identified as penisimplicissin $(7,0.5, \mathrm{mg}$, $\mathrm{R}_{\mathrm{f}} 0.29$ on TLC on silica gel eluting with $n$-hexane-acetone $\left.(6: 4, v / v)\right)$. Fraction $\mathrm{D}$ was purified using the same condition described for $C$ giving penicillide $\left(8,6.9, \mathrm{mg}, \mathrm{R}_{\mathrm{f}} 0.29\right.$ on TLC on silica gel eluent $n$-hexane-acetone $(6: 4, v / v))$ as amorphous solid. Finally, the residue of fraction $\mathrm{F}$ was further purified on TLC on silica gel eluting with $\mathrm{CHCl}_{3} /$ iso-PrOH $(9: 1, v / v)$ giving 1-glycerol-linoleate $\left(\mathbf{9}, 1.5 \mathrm{mg}, \mathrm{R}_{\mathrm{f}}\right.$ 0.40 on TLC on silica gel eluent $\mathrm{CHCl}_{3} /$ iso- $\left.\mathrm{PrOH}(9: 1, v / v)\right)$ as soft solid.

Talarodiolide (1): amorphous solid; UV $\left(\mathrm{CH}_{3} \mathrm{CN}\right) \lambda_{\max }(\log \varepsilon) 260$ (3.15); HRESIMS (+): 471.1990 ([calcd. 471.1995 for $\left.\mathrm{C}_{24} \mathrm{H}_{32} \mathrm{O}_{8} \mathrm{Na} 2 \mathrm{M}+\mathrm{Na}\right]^{+}$), 449.2182 ([calcd. 449.2175 for $\left.\mathrm{C}_{24} \mathrm{H}_{33} \mathrm{O}_{8} 2 \mathrm{M}+\mathrm{H}\right]^{+}$), 247.0950 ([calcd. 247.0941 for $\left.\mathrm{C}_{12} \mathrm{H}_{16} \mathrm{O}_{4} \mathrm{Na} \mathrm{M}+\mathrm{Na}\right]^{+}$), 225.1118 ([calcd. 225.1127 for $\left.\mathrm{C}_{12} \mathrm{H}_{17} \mathrm{O}_{4} \mathrm{M}+\mathrm{H}\right]^{+}$); ${ }^{1} \mathrm{H}-\mathrm{NMR}\left(\mathrm{CDCl}_{3}, 400 \mathrm{MHz}\right)$ and ${ }^{13} \mathrm{C}-\mathrm{NMR}\left(\mathrm{CDCl}_{3}, 100 \mathrm{MHz}\right)$ data: see Table 1. 
Cyclo-(S-Pro-R-Leu) (3): amorphous solid; $[\alpha]_{\mathrm{D}}-88^{\circ}\left(\mathrm{c}=0.12, \mathrm{C}_{2} \mathrm{H}_{5} \mathrm{OH}\right) ;$ HRESIMS (+): 443.2636 ([calcd. 443.2629 for $\left.\mathrm{C}_{22} \mathrm{H}_{36} \mathrm{~N}_{4} \mathrm{O}_{4} \mathrm{Na} 2 \mathrm{M}+\mathrm{Na}\right]^{+}$), 233.1269 ([calcd. 233.1260 for $\mathrm{C}_{11} \mathrm{H}_{18} \mathrm{~N}_{2} \mathrm{O}_{2} \mathrm{Na} \mathrm{M}+$ $\left.\mathrm{Na}]^{+}\right), 211.1448$ ([calcd. 211.1441 for $\left.\mathrm{C}_{11} \mathrm{H}_{19} \mathrm{~N}_{2} \mathrm{O}_{2} \mathrm{M}+\mathrm{H}\right]^{+}$). Optical rotation and NMR data are in agreement with those previously reported [20].

Cyclo-(S-Pro-S-Ile) (4): amorphous solid; $[\alpha]_{\mathrm{D}}-193^{\circ}\left(\mathrm{c}=0.11, \mathrm{C}_{2} \mathrm{H}_{5} \mathrm{OH}\right) ; \operatorname{HRESIMS}(+)$ : 233.1272 ([calcd. 233.1260 for $\left.\mathrm{C}_{11} \mathrm{H}_{18} \mathrm{~N}_{2} \mathrm{O}_{2} \mathrm{Na} \mathrm{M}+\mathrm{Na}\right]^{+}$), 211.1451 ([calcd. 211.1441 for $\mathrm{C}_{11} \mathrm{H}_{19} \mathrm{~N}_{2} \mathrm{O}_{2} \mathrm{M}+\mathrm{H}$ ] ${ }^{+}$); Optical rotation and NMR data are in agreement with those previously reported [20].

Cyclo-(S-Pro-S-Phe) (5): amorphous solid; $[\alpha]_{\mathrm{D}}-65^{\circ}\left(\mathrm{c}=0.10, \mathrm{CH}_{3} \mathrm{OH}\right)$; HRESIMS (+): 267.1115 ([calcd. 267.1109 for $\left.\mathrm{C}_{14} \mathrm{H}_{16} \mathrm{~N}_{2} \mathrm{O}_{2} \mathrm{Na} \mathrm{M}+\mathrm{Na}\right]^{+}$), 245.1296 ([calcd. 245.1290 for $\left.\mathrm{C}_{14} \mathrm{H}_{17} \mathrm{~N}_{2} \mathrm{O}_{2} \mathrm{M}+\mathrm{H}\right]^{+}$); Optical rotation and NMR data are in agreement with those previously reported [21].

Vermistatin (6): crystalline compound; $[\alpha]_{\mathrm{D}}-6^{\circ}\left(\mathrm{c}=0.14, \mathrm{CHCl}_{3}\right)$; HRESIMS (+): 351.0841 ([calcd. 351.0845 for $\left.\mathrm{C}_{18} \mathrm{H}_{16} \mathrm{O}_{6} \mathrm{Na} \mathrm{M}+\mathrm{Na}\right]^{+}$), 329.1025 ([calcd. 329.1029 for $\left.\mathrm{C}_{18} \mathrm{H}_{17} \mathrm{O}_{6} \mathrm{M}+\mathrm{H}\right]^{+}$). Optical rotation and NMR data are in agreement with those previously reported [23].

Penisimplicissin (7): amorphous solid; $[\alpha]_{\mathrm{D}}-112^{\circ}\left(\mathrm{c}=0.15, \mathrm{CHCl}_{3}\right)$; HRESIMS (+): 627.1475 ([calcd. 627.1473 for $\left.\mathrm{C}_{32} \mathrm{H}_{28} \mathrm{O}_{12} \mathrm{Na} 2 \mathrm{M}+\mathrm{Na}\right]^{+}$), 325.0686 ([calcd. 325.0683 for $\left.\mathrm{C}_{16} \mathrm{H}_{14} \mathrm{O}_{6} \mathrm{Na} \mathrm{M}+\mathrm{Na}\right]^{+}$), 303.0869 ([calcd. 303.0863 for $\left.\mathrm{C}_{16} \mathrm{H}_{15} \mathrm{O}_{6} \mathrm{M}+\mathrm{H}\right]^{+}$). Optical rotation and NMR data are in agreement with those previously reported [24].

Penicillide (8): amorphous solid; $[\alpha]_{\mathrm{D}}+6^{\circ}\left(\mathrm{c}=0.16, \mathrm{CHCl}_{3}\right)$; HRESIMS (+): 409.2565 ([calcd. 409.1627 for $\left.\mathrm{C}_{22} \mathrm{H}_{26} \mathrm{O}_{6} \mathrm{Na} \mathrm{M}+\mathrm{Na}\right]^{+}$), 371.1493 ([calcd. 371.1489 for $\left.\left.\mathrm{C}_{21} \mathrm{H}_{23} \mathrm{O}_{6} \mathrm{M}-\mathrm{CH}_{3}\right]^{+}\right), 359[\mathrm{M}+\mathrm{H}-\mathrm{CO}]^{+}$. Optical rotation and NMR data are in agreement with those previously reported ([25] and literature therein).

\subsection{GC/MS Analysis}

GC/MS data were acquired on crude extracts or isolated metabolites. The metabolite identities were confirmed acquiring mass spectra of pure compounds and high-quality mass spectra were obtained employing the National Institute of Standards and Technology (NIST) deconvolution software Automatic Mass spectral Deconvolution \& Identification System (AMDIS) [29,30]. Mass spectra were stored in the custom MS target library of metabolites [31]. Fatty acids and esters of fatty acids were identified by comparing their mass spectra with spectra of pure compounds gathered in the database NIST 14 Mass Spectral library [27] by employing the NIST Mass Spectral Search Program v.2.og [32].

\section{Conclusions}

The present paper describes the isolation and structural characterization of the first 12-membered macrodiolide, named talarodiolide, from the culture filtrate of strain LT6 of T. pinophilus. We expect we will be able to isolate sufficient amount of talarodiolide for biological studies. Furthermore, the identification of metabolites present in culture filtrate and mycelial extracts of this strain was carried out with the support of a custom GC/MS library mainly built after isolation and identification of metabolites via NMR spectroscopy. This strategy represents a suitable approach for the screening, with high confidence, of several metabolites present in crude extracts and future works will focus on testing the effects of experimental conditions (i.e., media composition, co-cultivation with other microbes, etc.) on the production of secondary metabolites by strains of T. pinophilus.

Supplementary Materials: The following are available online. NMR spectra of talarodiolide; EI mass spectra at $70 \mathrm{eV}$ of metabolites from T. pinophilus.

Acknowledgments: We are grateful to Francesco Borrillo for assistance with processing the samples. 
Author Contributions: M.M.S., M.D., R.N. and A.A. conceived and organized the manuscript and wrote the text; R.N. and F.V. cultivated the fungal strain; M.D. and A.A. performed the NMR analysis; M.M.S., F.S, F.V. and D.N. performed the GC/MS analysis; and M.D., R.N, F.S. and A.A. edited and reviewed the manuscript.

Conflicts of Interest: The authors declare no conflict of interest.

\section{References}

1. Nicoletti, R.; De Stefano, M.; De Stefano, S.; Trincone, A.; Marziano, F. Antagonism against Rhizoctonia solani and fungitoxic metabolite production by some Penicillium isolates. Mycopathologia 2004, 158, 465-474. [CrossRef] [PubMed]

2. Nicoletti, R.; Trincone, A. Bioactive compounds produced by strains of Penicillium and Talaromyces of marine origin. Mar. Drugs 2016, 14, 37. [CrossRef] [PubMed]

3. Nicoletti, R.; Salvatore, M.M.; Andolfi, A. Secondary matabolites of mangrove-associated strains of Talaromyces. Mar. Drugs 2018, 16, 12. [CrossRef] [PubMed]

4. Pandey, A.; Das, N.; Kumar, B.; Rinu, K.; Trivedi, P. Phosphate solubilization by Penicillium spp. isolated from soil samples of Indian Himalayan region. World J. Microbiol. Biotechnol. 2008, 24, 97-102. [CrossRef]

5. Wani, Z.A.; Mirza, D.N.; Arora, P.; Riyaz-Ul-Hassan, S. Molecular phylogeny, diversity, community structure, and plant growth promoting properties of fungal endophytes associated with the corms of saffron plant: An insight into the microbiome of Crocus sativus Linn. Fungal Biol. 2016, 120, 1509-1524. [CrossRef] [PubMed]

6. Hansen, G.H.; Lübeck, M.; Frisvad, J.C.; Lübeck, P.S.; Andersen, B. Production of cellulolytic enzymes from ascomycetes: Comparison of solid state and submerged fermentation. Process Biochem. 2015, 50, 1327-1341. [CrossRef]

7. Li, C.X.; Zhao, S.; Zhang, T.; Xian, L.; Liao, L.S.; Liu, J.L.; Feng, J.X. Genome sequencing and analysis of Talaromyces pinophilus provide insights into biotechnological applications. Sci. Rep. 2017, 7, 490. [CrossRef] [PubMed]

8. Ohte, S.; Matsuda, D.; Uchida, R.; Nonaka, K.; Masuma, R.; Ōmura, S.; Tomoda, H. Dinapinones, novel inhibitors of triacylglycerol synthesis in mammalian cells, produced by Penicillium pinophilum FKI-3864. J. Antibiot. 2011, 64, 489-494. [CrossRef] [PubMed]

9. Nicoletti, R.; Scognamiglio, M.; Fiorentino, A. Structural and bioactive properties of 3-O-methylfunicone. Mini Rev. Med. Chem. 2014, 14, 1043-1047. [CrossRef]

10. Zhai, M.M.; Li, J.; Jiang, C.X.; Shi, Y.P.; Di, D.L.; Crews, P.; Wu, Q.X. The bioactive secondary metabolites from Talaromyces species. Nat. Prod. Bioprospect. 2016, 6, 1-24. [CrossRef] [PubMed]

11. De Stefano, S.; Nicoletti, R.; Milone, A.; Zambardino, S. 3-O-Methylfunicone, a fungitoxic metabolite produced by the fungus Penicillium pinophilum. Phytochemistry 1999, 52, 1399-1401. [CrossRef]

12. Nicoletti, R.; Manzo, E.; Ciavatta, L. Occurence and bioactivities of funicone-related compounds. Int. J. Mol. Sci. 2009, 10, 1430-1444. [CrossRef] [PubMed]

13. Buommino, E.; Paoletti, I.; De Filippis, A.; Nicoletti, R.; Ciavatta, M.L.; Menegozzo, S.; Menegozzo, M.; Tufano, M.A. 3-O-Methylfunicone, a metabolite produced by Penicillium pinophilum, modulates ERK1/2 activity, affecting cell motility of human mesothelioma cells. Cell Prolif. 2010, 43, 114-123. [CrossRef] [PubMed]

14. Buommino, E.; Tirino, V.; De Filippis, A.; Silvestri, F.; Nicoletti, R.; Ciavatta, M.L.; Pirozzi, G.; Tufano, M.A. 3-O-Methylfunicone, from Penicillium pinophilum, is a selective inhibitor of breast cancer stem cells. Cell Prolif. 2011, 44, 401-409. [CrossRef] [PubMed]

15. Buommino, E.; De Filippis, A.; Nicoletti, R.; Menegozzo, M.; Menegozzo, S.; Ciavatta, M.L.; Rizzo, A.; Brancato, V.; Tufano, M.A.; Donnarumma, G. Cell-growth and migration inhibition of human mesothelioma cells induced by 3-O-methylfunicone from Penicillium pinophilum and cisplatin. Investig. New Drugs 2012, 30, 1343-1351. [CrossRef] [PubMed] 
16. Nicoletti, R.; Buommino, E.; De Filippis, A.; Lopez-Gresa, M.P.; Manzo, E.; Carella, A.; Petrazzuolo, M.; Tufano, M.A. Bioprospecting for antagonistic Penicillium strains as a resource of new antitumor compounds. World J. Microbiol. Biotechnol. 2008, 24, 189-195. [CrossRef]

17. Baroni, A.; De Luca, A.; De Filippis, A.; Petrazzuolo, M.; Manente, L.; Nicoletti, R.; Tufano, M.A.; Buommino, E. 3-O-methylfunicone, a metabolite of Penicillium pinophilum, inhibits proliferation of human melanoma cells by causing $\mathrm{G}_{2}+\mathrm{M}$ arrest and inducing apoptosis. Cell Prolif. 2009, 42, 541-553. [CrossRef] [PubMed]

18. De Stefano, S.; Nicoletti, R.; Zambardino, S.; Milone, A. Structure elucidation of a novel funicone-like compound produced by Penicillium pinophilum. Nat. Prod. Lett. 2002, 16, 207-211. [CrossRef] [PubMed]

19. Ciavatta, M.L.; Manzo, E.; Contillo, R.; Nicoletti, R. Methoxyvermistatin production by Penicillium pinophilum isolate LT4. In Proceedings of the 4th Congress of European Microbiologists (FEMS 2011), Geneva, Switzerland, 26-30 June 2011.

20. Adamczeski, M.; Reed, A.R.; Crews, P. New and known diketopiperazines from the Caribbean sponge, Calyx cf. podatypa. J. Nat. Prod. 1995, 58, 201-208. [CrossRef] [PubMed]

21. Wang, G.; Dai, S.; Chen, M.; Wu, H.; Xie, L.; Luo, X.; Li, X. Two diketopiperazine cyclo-(Pro-Phe) isomers from marine bacteria Bacillus subtilis sp. 13-2. Chem. Nat. Compd. 2010, 46, 583-585. [CrossRef]

22. Mazri, R.; Belaidi, S.; Kerassa, A.; Lanez, T. Conformational analysis, substituent effect and structure activity relationships of 16-membered macrodiolides. Int. Lett. Chem. Phys. Astron. 2014, 14, 146-167. [CrossRef]

23. Fuska, J.; Uhrin, D.; Proksa, B.; Votický, Z.; Ruppeldt, J. The structure of vermistatin, a new metabolite from Penicillium vermiculatum. J. Antibiot. 1986, 39, 1605-1608. [CrossRef] [PubMed]

24. Komai, S.I.; Hosoe, T.; Itabashi, T.; Nozawa, K.; Yaguchi, T.; Fukushima, K.; Kawai, K. New vermistatin derivatives isolated from Penicillium simplicissimum. Heterocycles 2005, 11, 2771-2776.

25. Komai, S.I.; Hosoe, T.; Itabashi, T.; Nozawa, K.; Yaguchi, T.; Fukushima, K.; Kawai, K.I. New penicillide derivatives isolated from Penicillium simplicissimum. J. Nat. Med. 2006, 60, 185-190. [CrossRef] [PubMed]

26. Nieva-Echevarría, B.; Goicoechea, E.; Manzanos, M.J.; Guillén, M.D. A method based on ${ }^{1}$ H-NMR spectral data useful to evaluate the hydrolysis level in complex lipid mixtures. Food Res. Int. 2014, 66, 379-387. [CrossRef]

27. NIST Standard Reference Data. Available online: http://www.nist.gov/srd/nist1a.cfm (accessed on 20 March 2018).

28. Vinale, F.; Nicoletti, R.; Lacatena, F.; Marra, R.; Sacco, A.; Lombardi, N.; d'Errico, G.; Digilio, M.C.; Lorito, M.; Woo, S.L. Secondary metabolites from the endophytic fungus Talaromyces pinophilus. Nat. Prod. Res. 2017, 31, 1778-1785. [CrossRef] [PubMed]

29. AMDIS NET. Available online: http:/ / www.amdis.net/ (accessed on 20 March 2018).

30. Stein, S.E. An integrated method for spectrum extraction and compound identification from GC/MS data. J. Am. Soc. Mass Spectrom. 1999, 10, 770-781. [CrossRef]

31. Schauer, N.; Steinhauser, D.; Strelkov, S.; Schomburg, D.; Allison, G.; Moritz, T.; Lundgren, K.; Roessner-Tunali, U.; Forbes, M.G.; Willmitzer, L.; et al. GC-MS libraries for the rapid identification of metabolites in complex biological samples. FEBS Lett. 2005, 579, 1332-1337. [CrossRef] [PubMed]

32. Hummel, J.; Strehmel, N.; Selbig, J.; Walther, D.; Kopka, J. Decision tree supported substructure prediction of metabolites from GC-MS profiles. Metabolomics 2010, 6, 322-333. [CrossRef] [PubMed]

Sample Availability: Samples of the compounds 1-9 are available from the authors. 